\title{
CHARACTERIZATION OF ROTAVIRUS P GENOTYPES CIRCULATING AMONG PAEDIATRIC INPATIENTS IN NORTHERN BRAZIL
}

\author{
Joana D'Arc P. MASCARENHAS(1), Rosa Helena P. GUSMÃo(1), Célia R. M. BARARDI(2), Fernanda L. PAIVA(2), Cláudia O. SIMõeS(2),
}

Yvone B. GABBAY(1), Talita A. F. MONTEIRO(1) \& Alexandre C. LINHARES(1)

\begin{abstract}
SUMMARY
Between November 1992 and August 1993, twenty-eight rotavirus-positive stool samples obtained from paediatric inpatients in Belém, Brazil, aged less than four years, were tested by RT-PCR to determine the P genotype specificities. With the exception of 7 non-diarrhoeic children, all patients were either diarrhoeic at admission or developed diarrhoea while in hospital. Rotavirus strains with the gene 4 alleles corresponding to $\mathrm{P} 1 \mathrm{~B}[4]$ and $\mathrm{P} 1 \mathrm{~A}[8]$ types (both of which bearing $\mathrm{G} 2$ specificity) predominated, accounting for $78.6 \%$ of the strains. While only one P2A[6] type strain - with (mixed) G1 and 4 type specificities - was detected, the gene 4 allele could not be identified in $4(14.3 \%)$ of the strains. Most $(81 \%)$ of the specimens were obtained from children during their first 18 months of life. Rotavirus strains bearing single P1B[4] type-specificity were identified in both diarrhoeic (either nosocomial, 28.6\% or community-acquired diarrhoea, 28.6\%) and non-diarrhoeic (42.8\%) children. P1A[8] gene 4 allele, on the other hand, was detected only among diarrhoeic children, at rates of $57.1 \%$ and $42.9 \%$ for nosocomial- and- community acquired diarrhoea, respectively. Mixed P1A[8],1B[4] type infection was identified in only one case of community-acquired diarrhoea.
\end{abstract}

KEYWORDS: Rotavirus; P types; Diarrhoea; Hospitalized children.

\section{INTRODUCTION}

Group A rotaviruses are largely recognized as the single most important known aetiological agents of acute gastroenteritis in both infants and young children worldwide ${ }^{16}$. As licensure of a rotavirus vaccine for general use approaches, it becomes of growing importance to monitor circulating strains, particularly in the developing regions of the world ${ }^{5}$. The currently adopted dual typing classification system for rotavirus is based on antigenic specificities of two outer capsid proteins, VP7 and VP4, which independently elicit type-specific neutralizing antibodies $^{6}$. VP7 is a glycoprotein whereas VP4 is a protease-sensitive antigen; rotavirus $\mathrm{G}$ and $\mathrm{P}$ types are defined by the former and latter capsid proteins, respectively. On a global scale, 10 rotavirus $\mathrm{G}$ types (G1-4, G5, G6, G8-10 and G12) have been identified infecting humans, but only $\mathrm{G}$ serotypes 1 to 4 seem to be of major importance in terms of illness in most parts of the world ${ }^{9}$. In recent surveillance studies in Brazil, however, it has been demonstrated that G5, G8 and G10 may account for a significant proportion of cases of acute diarrhoea among infants and young children ${ }^{11,17,28}$. On the basis of neutralization assays, at least six distinct $P$ serotypes $(1,2,3,4,5$ and 11) have been identified among rotavirus strains of human origin, of which types/subtypes P1A and $\mathrm{P} 1 \mathrm{~B}$ are the most prevalent worldwide ${ }^{9}$. Recent nucleotide and aminoacid sequence analyses, on the other hand, allowed the identification of six distinct rotavirus VP4 genotypes in humans, designated as $\mathrm{P}[4], \mathrm{P}[6], \mathrm{P}[8], \mathrm{P}[9]$ and $\mathrm{P}[12]^{7}$. It has been established that human rotaviruses of $\mathrm{P}$ genotypes $4,6,8$ and 9 represent $\mathrm{P}$ serotypes $1 \mathrm{~B}, 2 \mathrm{~A}$, $1 \mathrm{~A}$ and 3, respectively. With the exception of India, where P[6] strains with G1, 2, 3, 4 or 9 specificities are common ${ }^{26}$, studies conducted in various parts of the world - including Brazil - indicate that P[8]G1, $\mathrm{P}[4] \mathrm{G} 2, \mathrm{P}[8] \mathrm{G} 3, \mathrm{P}[8] \mathrm{G} 4$ and $\mathrm{P}[4] \mathrm{G} 2$ rotavirus types are predominant $^{9,17,32}$. Furthermore, human isolates with other P-type specificities have been identified more rarely including $\mathrm{P}[9]$, associated with strains having G1, G2, G3 or G6-serotype specificity, and P[10], P[11] and $\mathrm{P}[14]$ which were found in association with G8, G9 and G6 specificities, respectively ${ }^{10,13,14}$.

In Northern Brazil, studies aiming the characterization of rotavirus $P$ types have focussed only on strains that circulate among infants and young children at community level, i.e. mostly associated with mild/moderate diarrhoeal cases ${ }^{21}$. In this study, both $\mathrm{P} 1 \mathrm{~A}[8]$ and $\mathrm{P} 1 \mathrm{~B}[4]$ rotavirus strains, with $\mathrm{G} 1$ type specificity, were found to predominate, accounting for $29 \%$ and $18 \%$ of typed strains, respectively. This report presents results of the first P-typing of rotavirus strains infecting hospitalized children in Northern Brazil who in general developed either severe or very severe diarrhoea.

\section{PATIENTS AND METHODS}

The 28 infants and young children under investigation were aged 0 to 3 years and had been primarily enrolled to participate in a previous 


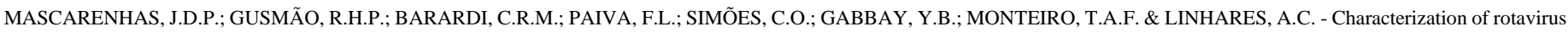
P genotypes circulating among paediatric inpatients in northern Brazil. Rev. Inst. Med. trop. S. Paulo, 41 (3): 165-170, 1999.

hospital-based survey of rotavirus subgroups, serotypes and electropherotypes in Belém, Eastern Amazon ${ }^{12}$. These patients were admitted to a paediatric ward of a large public hospital in Belém, Brazil in the period of November 1992 to August 1993. Diarrhoeal episodes were defined as three or more liquid or semi-liquid motions in a 24-hour period and patients were categorized into three sex- and age- matched groups, as follows: (a) nosocomial, including those who developed diarrhoea at least three days after admission; (b) community-acquired, represented by children who were either diarrhoeic at admission or developed diarrhoea within $72 \mathrm{~h}$ of hospitalization; and (c) non-diarrhoeic, which included cases in which no diarrhoea was detected at least three days before and three days after collection of faecal sample. Signed informed consents were obtained upon admission from parents of participating infants and young children.

Single faecal specimens were obtained from each diarrhoeic- andnon-diarrhoeic child during the acute phase of gastroenteritis and kept frozen at $-20{ }^{\circ} \mathrm{C}$ until being processed. Stool specimens were placed in phosphate buffered saline (PBS), $\mathrm{pH} 7.4$, for rotavirus screening by a commercial kit (DAKOPATTS ELISA, Copenhagen, Denmark), as originally reported by FLEWETT et al. ${ }^{8}$. The subsequent rotavirus G-serotyping was performed through a technique that uses monoclonal antibodies developed against each of the four (1 to 4) most common human serotypes ${ }^{31}$. The reverse-transcription and polymerase chain reaction (RT-PCR) P-typing procedures have been described in details elsewhere ${ }^{21,33}$. Briefly, the dsRNA was first reverse transcribed and amplified by PCR through two successive steps in which both consensus and nested primers were used. The first amplification was performed in the presence of primers designed to amplify an 1084 base pairs (bp) DNA fragment, corresponding to VP4 gene of strain KU, which is highly conserved among human rotavirus strains regardless of the difference in their P types or gene 4 alleles. In the second amplification, the fragment of $1084 \mathrm{bp}$ was used as a template with a mixture of P-type primers designed to generate DNA fragment lenghts of $338 \mathrm{bp}, 498 \mathrm{bp}$, $745 \mathrm{bp}$ and $911 \mathrm{pb}$, corresponding to $\mathrm{P}[4], \mathrm{P}[8], \mathrm{P}[6]$ and $\mathrm{P}[9]$ gene 4 alleles, respectively. The analysis of PCR products was made by electrophoresis on $1 \%$ agarose in Tris-borate-EDTA buffer containing ethidium bromide at a concentration of $1 \mathrm{ug} / \mathrm{mL}$.

\section{RESULTS}

The gene 4 allele specificities could be determined in $24(85.7 \%)$ of the 28 rotavirus-positive samples (Fig. 1). Rotavirus strains bearing $\mathrm{P} 1 \mathrm{~B}[4]$ specificity were largely predominant $(50.0 \%$ of tested samples), followed by samples typed as P1A[8] (28.6\%). Both groups of strains were previously ${ }^{12}$ serotyped as G2 (G-serotypes not shown in figure). The $\mathrm{P} 2 \mathrm{~A}[6]$ rotavirus type was assigned to $1(3.6 \%)$ strain, that also beared both $\mathrm{G} 1$ and 4 serotype specificities. An additional G2 strain with mixed P1A[8] and P1B[4] VP4 genotype specificities was identified. The electrophoretic analysis of the RT-PCR products after second amplification with these 24 stool samples is shown in Fig. 2 (A and B). The $\mathrm{P} 1 \mathrm{~B}[4]$ gene 4 allele was the most prevalent, followed by samples with P1A[8] specificity; lane A3 shows 2 DNA bands corresponding to $\mathrm{P} 1 \mathrm{~A}[8]$ and $\mathrm{P} 1 \mathrm{~B}[4]$ gene 4 alleles, whereas lane A16 demonstrates the only strain displaying P2A[6] VP4 specificity. Figure 3 shows the distribution of rotavirus $\mathrm{P}$ (and $\mathrm{G}$ ) types according to the age, specifying whether infections are symptomatic (either nosocomial or communityacquired diarrhoeal cases) or asymptomatic. Over $80 \%$ of rotavirus
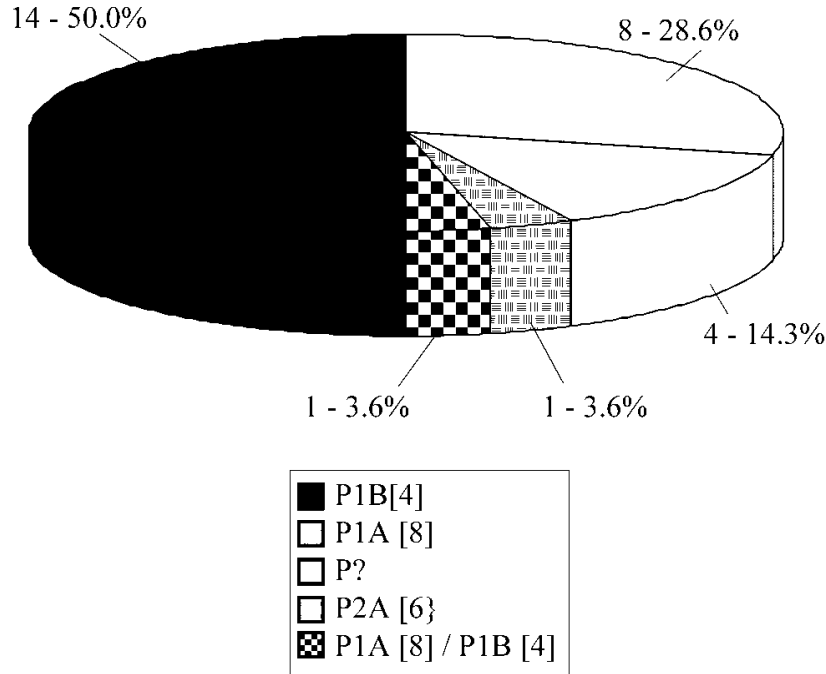

Fig. 1 - Occurrence of rotavirus $\mathrm{P}$ genotypes among hospitalized paediatric patients in Belém, Brazil.

strains were obtained from children within their first 18 months of age. The VP4 P1B[4] (with VP7 G2) specificity could be identified at comparable rates between symptomatic $(57.2 \%$; $28.6 \%$, nosocomialand- $28.6 \%$, community-acquired diarrhoea) and non-diarrhoeic $(42.8 \%)$ children. All rotavirus strains bearing P1A[8] type-specificity were from diarrhoeic patients, at rates of $57.1 \%$ and $42.9 \%$ for nosocomial- and- community-acquired diarrhoeal cases, respectively. The (single) P2A[6] and (mixed) P1A[8], P1B[4]-type infections involved one child, aged 15 months, with community-acquired diarrhoea.

\section{DISCUSSION}

Since the large-scale use of an effective vaccine is approaching, it is becoming of growing importance to proceed with a routine surveillance for rotavirus strains that circulate among diarrhoeic children, particularly in the developing areas of the world. In this context, particular attention should be focussed on the characterization of rotavirus $\mathrm{P}$ types, mainly because there is accumulating evidence that antibody to VP4 seems to play a major role in protecting against rotaviral disease $\mathrm{e}^{22}$. In addition, the viral haemagglutinin VP4 appears to have a role in viral virulence 4 .

Although several investigations throughout the world have documented the relative frequency and distribution of VP4 genotypes in cases of infantile diarrhoea ${ }^{1,9,25,30}$, studies carried out in Brazil are still scarce $^{17,32}$. In Northern Brazil, for example, the only available data on the occurrence of rotavirus P-types are those relating to strains obtained from children followed-up during a community-based, prospective study carried out from 1983 to $1986^{21}$.

In the present investigation, most of the samples were classified as either $\mathrm{P} 1 \mathrm{~B}[4](50 \%)$ or $\mathrm{P} 1 \mathrm{~A}[8](30 \%)$, which are essentially those strains most commonly found worldwide, including Brazil ${ }^{1,9,17,25}$. In our study, however, the relative frequencies of these VP4 genotypes are different from those reported in previous investigations in Brazil, and even elsewhere, where rotavirus strains bearing P1A[8] type-specificity 
A)
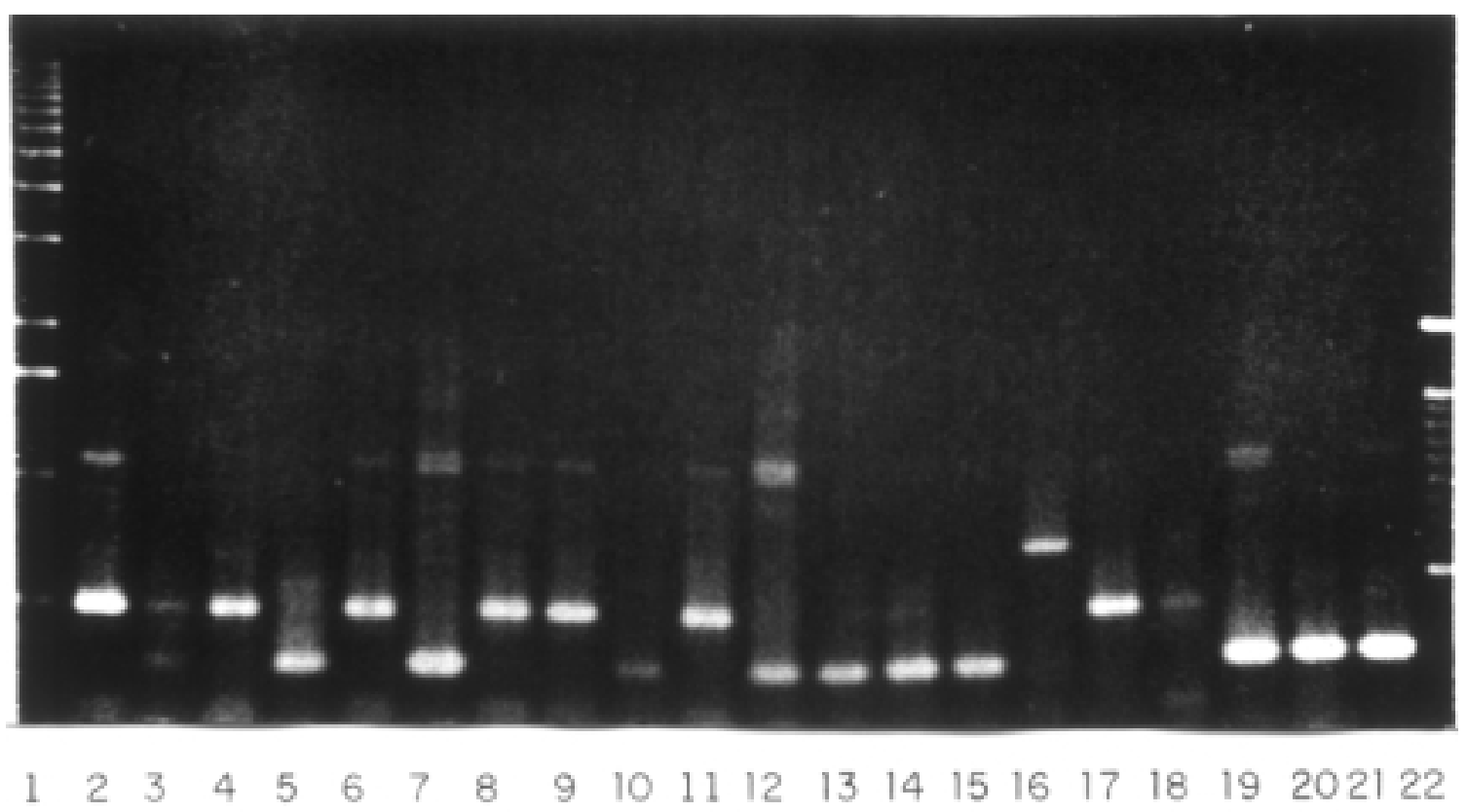

B)

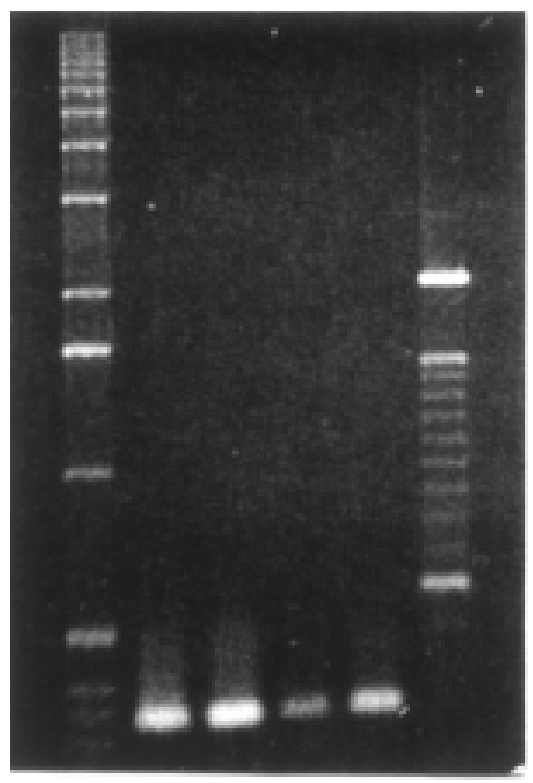

1

Fig. 2 - (A and B) - RT-PCR typing of rotavirus strains obtained from 24 hospitalized paediatric patients in Belém, Brazil. Lanes A1 and B1, molecular weight markers (1 Kb ladder; Gibco BRL, Long Island, N.Y.); Lanes A2, A4, A6, A8, A9, A11, A17 and A18, P1A[8] rotavirus P type; lane A3, P1A[8]+P1B[4]; lanes A5, A7, A10, A12, A13, A14, A15, A19, A20 and A21, P1B[4]; lane A16, P2A[6]; lanes A22 and B6, 100-bp molecular weight markers (Gibco BRL); and lanes B2, B3, B4 and B5, P1B[4].

usually predominated over those $\mathrm{P} 1 \mathrm{~B}[4]^{9,17}$. In the survey conducted by LEITE et al. ${ }^{17}$ in Brazil, for example, rotavirus strains genotyped as P[8] (serotypes not available) were largely predominant, accounting for over $60 \%$ of tested samples. These diverging results suggest that rotavirus P-types seem to co-circulate within the same country at prevalence rates that may differ significantly from one region to another. Our findings are also in contrast with those from a previous gene 4 allele characterization of rotavirus strains obtained during a longitudinal, commu- nity-based study conducted in Belém during 1983-1986 ${ }^{21}$. In this study, rotavirus strains genotyped as $\mathrm{P}[8]$ were found to predominate, accounting for almost a third of those P-typed samples. Since studies under comparison were carried out in Belém 10 years apart from each other, such findings support the view that the predominant rotavirus type appears to change over time within the same region ${ }^{2,12}$. Moreover, it seems unlikely that differences in the prevalent P-types between these two studies can be attributable to the origin (i.e. whether community - 


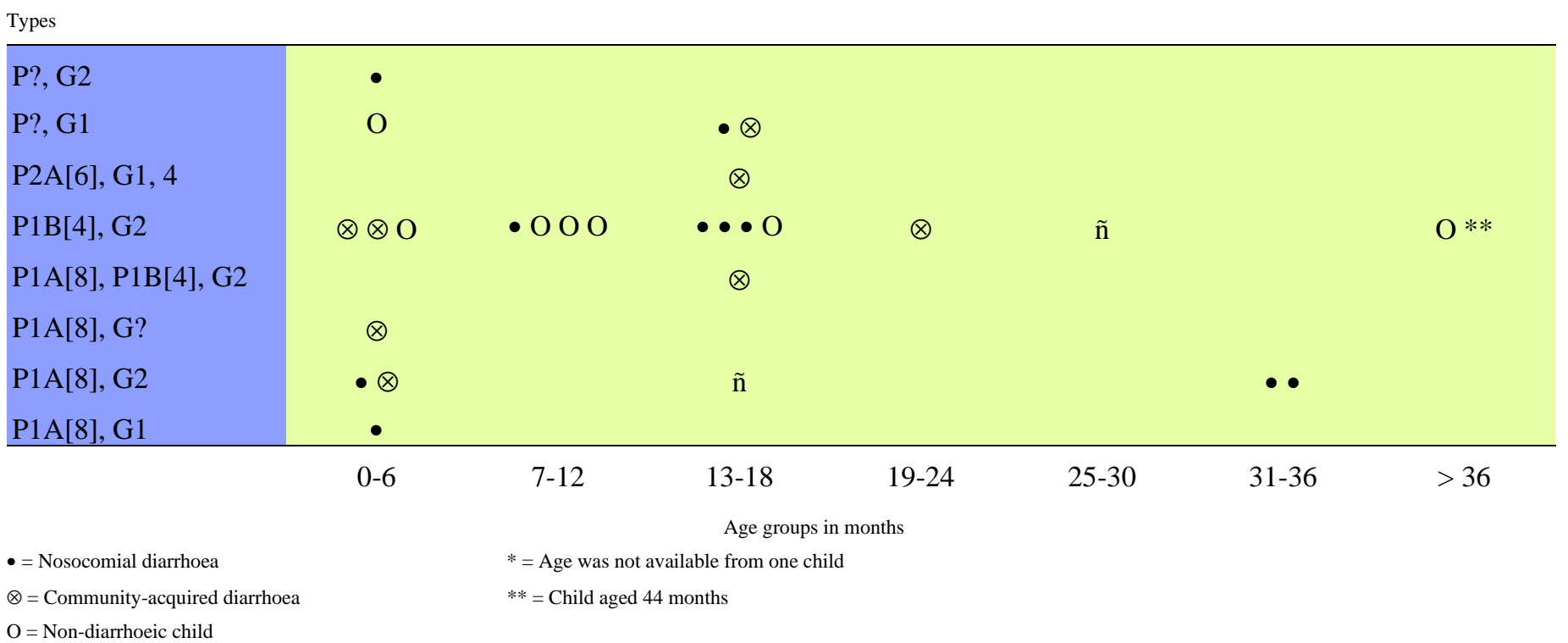

Fig. 3 - Age-distribution of rotavirus types among hospitalized paediatric patients in Belém, Brazil.

or hospital-acquired infection) of rotavirus isolates. While in the 19831986 investigation samples were obtained from mild/moderate diarrhoeal cases at community level, faecal specimens in the present study were collected from hospitalized children suffering from severe/very severe diarrhoea. Indeed, as demonstrated in previous surveys in Belém, rotavirus strains which circulate in hospital environment essentially reflect those prevalent in the external community ${ }^{12}$.

Only one (3.6\%) mixed rotavirus P-type (P1A[8] plus $\mathrm{P} 1 \mathrm{~B}[4])$ infection could be identified in the present study, a proportion that is significantly lower than it has been observed previously (around 20\%) in other VP4-genotyping surveys conducted in Brazil ${ }^{17,21}$. It could be postulated that the comparatively low rate of mixed rotavirus P-type infections may be associated with the high (about 50\%) proportion of nosocomial diarrhoeal cases, which are mostly associated with one or 2 (largely predominant) strains circulating at hospital environment: $\mathrm{P} 1 \mathrm{~B}[4]$ and $\mathrm{P} 1 \mathrm{~A}[8]$ types in the present study.

There was only one strain characterized as P2A[6] that also showed a dual G (1 plus 4) serotype-specificity, as based on reactivity patterns yielded previously by using monoclonal antibodies ${ }^{12}$. The fact that such a sample was obtained from a 15-month old child with (community-acquired) diarrhoea is in contrast with previous observations indicating that rotavirus $\mathrm{P}[6]$ genotype is in general associated with asymptomatically-infected neonates born in hospital nurseries ${ }^{3,27,29,30}$. Of interest, in a recently completed study in Belém, P[6], G2 strains have been detected in over $80 \%$ of newborn babies in obstetric hospital nurseries who became infected nosocomially with rotavirus, usually without symptoms of diarrhoea (MASCARENHAS et al., unpublished data).

It can be hypothesized that possible other (unconventional) $\mathrm{P}$ rotavirus types (e.g. $\mathrm{P}[9], \mathrm{P}[10], \mathrm{P}[11]$ and $\mathrm{P}[14]$ ) might have been circulating among hospitalized children in the present study, since a $P$ genotype could not be assigned to about $15 \%$ of the examined strains. As based on the antigenic composition of the only currently licensed rotavirus vaccine, these findings may have potential implications regarding future immunization strategies in Brazil.

A finding requiring further confirmation in our study (possibly through $\mathrm{G}$ genotyping and hybridization analyses) is that indicating that $2 / 3$ of the $\mathrm{P}[8]$ genotype-bearing rotavirus strains reacted as serotype $\mathrm{G} 2$ when assayed previously against G1 to 4 monoclonal antibodies ${ }^{12}$. This is in contrast with the established correlation between $\mathrm{P}$ genotypes and the serologically defined $G$ serotypes ${ }^{6,13}$, even though there has been accumulating evidence showing that nonserological typing methods do not necessarily reflect the antigenic diversity of the protein ${ }^{15,24}$. Such unusual $\mathrm{P}$ genotype/G serotype combination, however, also raises the question of possible naturally occurring genomic reassortments involving two distinct rotavirus strains that might have exchanged genes coding for VP4 and VP7 outer capsid proteins, as previously demonstrated $^{20,23}$.

Over $80 \%$ of the rotavirus-related diarrhoeal cases in the present study were identified among children aged less than 24 months, corroborating results from previous investigations in Belém, and elsewhere in the world, showing that the incidence of rotavirus gastroenteritis significantly decreases after the age of 2 years ${ }^{2,18,19}$. Of interest, while the VP4 $\mathrm{P} 1 \mathrm{~B}$ [4] (VP7 G2) type was detected at similar rates among diarrhoeic and non-diarrhoeic children, all rotavirus strains bearing P1A [8] (either VP7 G1 or VP7G2) specificity were identified among symptomatic inpatients. Although these results suggest the latter $\mathrm{P}$ genotype as being more virulent than the former one, no firm conclusion in this regard can yet be drawn from our data, since a low number of rotavirus strains has been included in the present study.

This report provides the first results concerning the $\mathrm{P}$ genotyping of rotavirus strains obtained from hospitalized children with severe, acute gastroenteritis in Northern Brazil, and should be regarded as prelimi- 


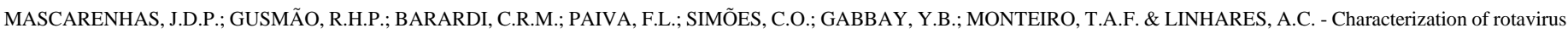
P genotypes circulating among paediatric inpatients in northern Brazil. Rev. Inst. Med. trop. S. Paulo, 41 (3): 165-170, 1999.

nary. A broader and more representative characterization of rotavirus $\mathrm{P}$ (and $\mathrm{G}$ ) types circulating in our area might be achieved through a continuous (namely hospital-based) surveillance involving several settings throughout the country. This knowledge will provide an important tool in the implementation of national rotavirus vaccination programs.

\section{RESUMO}

\section{Caracterização de genótipos $P$ de rotavírus circulantes entre pacientes pediátricos hospitalizados no norte do Brasil}

De novembro de 1992 a agosto de 1993, 28 amostras fecais positivas para rotavírus, obtidas de pacientes pediátricos hospitalizados em Belém, Brasil, com idades inferiores a 4 anos, foram testadas por $R T-P C R$ visando à determinação dos genótipos $\mathrm{P}$. Com exceção de 7 crianças não diarréicas, todos os pacientes apresentavam diarréia à admissão ou a desenvolviam enquanto internados no hospital. Cepas de rotavírus com especificidades antigênicas $\mathrm{P}$ correspondentes aos genótipos $\mathrm{P} 1 \mathrm{~B}[4]$ e $\mathrm{P} 1 \mathrm{~A}[8]$ (ambos pertencentes ao tipo G2) predominaram, representando $78,6 \%$ das amostras. Enquanto apenas uma cepa classificada como P2A[6] - com dupla especifidade antigênica (1 e 4) para o tipo $\mathrm{G}$ - foi detectada, não se identificou o genótipo $\mathrm{P}$ em 4 $(14,3 \%)$ das cepas sob exame. A maioria $(81 \%)$ dos espécimes fecais foi obtida de crianças com até 18 meses de vida. As cepas de rotavírus com genótipo único P1B [4] foram identificadas em crianças diarréicas (quer as infecções de origem nosocomial, 28,6\%, quer as oriundas da comunidade, 28,6\%), assim como entre as assintomáticas $(42,8 \%)$. O genótipo P1A[8], por outro lado, foi detectado somente entre pacientes com diarréia, com frequências de $57,1 \%$ e $42,9 \%$ entre os casos classificados como nosocomiais e de origem comunitária, respectivamente. Infecção mista envolvendo os genótipos P1A[8] e P1B[4] se caracterizou em apenas uma situação de infecção sintomática (gastroenterite) contraida na comunidade.

\section{ACKNOWLEDGMENTS}

We thank Maria do Socorro Rocha and Antônio de Moura for their invaluable technical support.

\section{REFERENCES}

1. ARISTA, S.; VIZZI, E.; FERRARO, D.; CASCIO, A. \& Di STEFANO, R. - Distribution of VP7 serotypes and VP4 genotypes among rotavirus strains recovered from Italian children with diarrhoea. Brief report. Arch. Virol., 142: 2065-2071, 1997.

2. BISHOP, R.F. - Natural history of rotavirus infection. Arch. Virol., 12 (suppl.): 119-128, 1996.

3. BISHOP, R.F.; BARNES, G.L.; CIPRIANI, E. \& LUND, J.S. - Clinical immunity after neonatal rotavirus infection: a prospective, longitudinal study in young children. New Engl. J. Med., 309: 72-76, 1983.

4. BLACKLOW, N.R. \& GREENBERG, H.B. - Viral gastroenteritis. New Engl. J. Med., 325: 252-264, 1991.

5. BRESEE, J. - Current status and future priorities for rotavirus vaccine development, evaluation and implementation in developing countries. Vaccine, 1999. (In press).

6. ESTES, M.K. - Advances in molecular biology: impact on rotavirus vaccine development. J. infect. Dis., 174 (suppl. 1): S37-S46, 1996.
7. ESTES, M.K. - Rotaviruses and their replication. In: FIELDS, B.N.; KNIPE, D.M.; HOWLEY, P.M. et al., ed. Fields Virology. Philadelphia, Lippincott; Raven, 1996 p. 1625-1655.

8. FLEWETT, T.H.; ARIAS, C.F.; AVENDÃNO, L.F. et al. - Comparative evaluation of the WHO and DAKOPATTS enzyme-linked immuno-assay kit for the rotavirus detection. Bull. Wld. Hlth. Org., 67: 369-374, 1989.

9. GENTSCH, J.R.; WOODS, P.A.; RAMACHANDRAN, M. et al. - Review of G and P typing results from a global collection of rotavirus strains: implications for vaccine development. J. infect. Dis., 174 (suppl. 1): S30-S36, 1996.

10. GERNA, S.; SEARS, J.; HOSHINO, Y. et al. - Identification of a new VP4 serotype of human rotaviruses. Virology, 200: 66-71, 1994.

11. GOUVEA, V.; CASTRO, L. de; TIMENETSKY, M.C.; GREENBERG, H. \& SANTOS, N. - Rotavirus serotype G5 associated with diarrhea in Brazilian children. J. clin. Microbiol., 32: 1408-1409, 1994.

12. GUSMÃO, R.H.P.; MASCARENHAS, J.D.P.; GABBAY, Y.B. et al. - Rotavirus subgroups, $\mathrm{G}$ serotypes and electrophoretypes in cases of nosocomial infantile diarrhoea in Belém, Brazil. J. trop. Pediat., 45: 81-86, 1999.

13. HOSHINO, Y. \& KAPIKIAN, A.Z. - Classification of rotavirus VP4 and VP7 serotypes. Arch. Virol., 12 (suppl.): 99-111, 1996.

14. HUSAIN, M.; SETH, P.; DAR, L. \& BROOR, S. - Classification of rotavirus into $G$ and $\mathrm{P}$ types with specimens from children with acute diarrhea in New Delhi, India. J. clin. Microbiol., 34: 1592-1594, 1996.

15. ISA, P. \& SNODGRASS, D.R. - Serological and genomic characterization of equine rotavirus VP4 proteins identifies three different P serotypes. Virology, 201: 364-372, 1994.

16. KAPIKIAN, A.Z. \& CHANOCK, R.M. - Rotaviruses. In: FIELDS, B.N.; KNIPE, D.N. HOWLEY, P.M. et al., ed. Fields Virology. Philadelphia, Lippincott; Raven, 1996 p. 1657-1708.

17. LEITE, J.P.G.; ALFIERI, A.A.; WOODS, P.A.; GLASS, R.I. \& GENTSCH, J.R. Rotavirus $\mathrm{G}$ and $\mathrm{P}$ types circulating in Brazil: characterization by RT-PCR, probe hybridization, and sequence analysis. Arch. Virol., 141: 2365-2374, 1996.

18. LINHARES, A.C.; MONÇÃO, H.C.; GABBAY, Y.B. et al. - Acute diarrhoea associated with rotavirus among children in Belém, Brazil. Trans. roy. Soc. trop. Med. Hyg., 77: 384-390, 1983.

19. LINHARES, A.C.; GABBAY, Y.B.; FREITAS, R.B. et al. - Longitudinal study of rotavirus infections among children from Belém, Brazil. Epidem. Infect., 102: 129-144, 1989.

20. MASCARENHAS, J.D.P.; LINHARES, A.C.; GABBAY, Y.B. et al. - Naturally occurring serotype 2, subgroup II rotavirus reassortants in Northern Brazil. Virus Res., 14: 235-240, 1989.

21. MASCARENHAS, J.D.P.; PAIVA, F.L.; BARARDI, C.R.M. et al. - Rotavirus G and P types in children from Belém, Northern Brazil, as determined by RT-PCR: occurrence of mixed P type infections. J. Diarrhoeal Dis. Res., 16: 8-14, 1998.

22. MATSUI, S.M.; OFFIT, P.A.; VO, P.T. et al. - Passive protection against rotavirus-induced diarrhea by monoclonal antibodies to the heterotypic neutralization domain of VP7 and the VP8 fragment of VP4. J. clin. Microbiol., 27: 780-782, 1989.

23. NAKAGOMI, O. \& NAKAGOMI, T. - Molecular evidence for naturally occurring single VP7 gene substitution reassortant between human rotaviruses belonging to two different genogroups. Arch. Virol., 119: 67-81, 1991 
MASCARENHAS, J.D.P.; GUSMÃO, R.H.P.; BARARDI, C.R.M.; PAIVA, F.L.; SIMÕES, C.O.; GABBAY, Y.B.; MONTEIRO, T.A.F. \& LINHARES, A.C. - Characterization of rotavirus P genotypes circulating among paediatric inpatients in northern Brazil. Rev. Inst. Med. trop. S. Paulo, 41 (3): 165-170, 1999.

24. NAKAGOMI, O.; ISEGAWA, Y.; HOSHINO, Y. et al. - A new serotype of the outer capsid protein VP4 shared by an unusual human rotavirus strain Ro1845 and canine rotaviruses. J. gen. Virol., 74: 2771-2774, 1993

25. PADILLA-NORIEGA, L.; MÉNDEZ-TOSS, M.; MENCHACA, G. et al. - Antigenic and genomic diversity of human rotavirus VP4 in two consecutive epidemic seasons in Mexico. J. clin. Microbiol., 36: 1688-1692, 1998.

26. RAMACHANDRAN, M.; DAS, B.K.; VIJ, A. et al. - Unusual diversity of human rotavirus G and P genotypes in India. J. clin. Microbiol., 34: 436-439, 1996.

27. SANTOS, N.; RIEPENHOFF-TALTY, M.; CLARK, H.F.; OFFIT, P. \& GOUVEA, V. - VP4 genotyping of human rotavirus in the United States. J. clin. Microbiol., 32: 205-208, 1994

28. SANTOS, N.; LIMA, R.C.C.; PEREIRA, C.F.A. \& GOUVEA, V. - Detection of rotavirus types G8 and G10 among Brazilian children with diarrhea. J. clin. Microbiol., 36: 2727-2729, 1998.

29. SILBERSTEIN, L.; SHULMAN, L.M.; MENDELSEN, E. \& SHIF, I. - Distribution of both rotavirus VP4 genotypes and VP7 serotypes among hospitalized and non-hospitalized Israeli children. J. clin. Microbiol., 33: 1421-1422, 1995.
30. STEELE, A.D.; van NIEKERK, M.C. \& MPHAHLELE, M.J. - Geographical distribution of human rotavirus VP4 genotypes and VP7 serotypes in five South African regions. J. clin. Microbiol., 33: 1516-1519, 1995.

31. TANIGUCHI, K.; URASAWA, T.; MORITA, Y.; GREENBERG, H.B. \& URASAWA, S. - Direct serotyping of human rotavirus in stool using serotype 1-, 2-, 3- and 4 specific monoclonal antibodies to VP7. J. infect. Dis., 155: 1159-1166, 1987.

32. TIMENETSKY, M.C.; SANTOS, N. \& GOUVEA, V. - Survey of rotavirus G and P types associated with human gastroenteritis in São Paulo, Brazil, from 1986 to 1992. J. clin. Microbiol., 32: 2622-2624, 1994.

33. WU, H.; TANIGUCHI, K.; WAKASUGI, F. et al. - Survey on the distribution of the gene 4 alleles of human rotaviruses by polymerase chain reaction. Epidem. Infect., 112: $615-622,1994$

Received: 01 February 1999

Accepted: 16 March 1999 